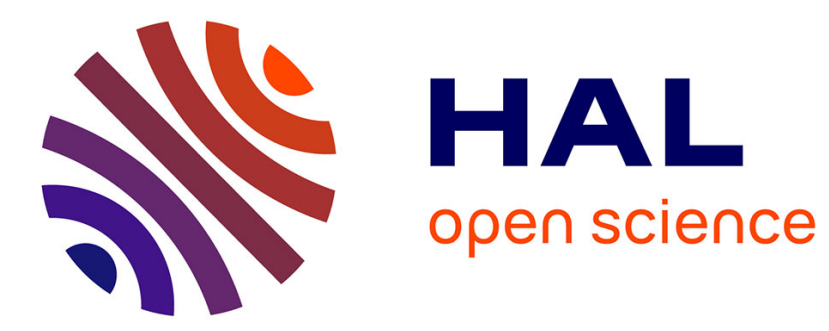

\title{
Confronting a Christian Neighbor: Sudanese Representations of Ethiopia in the Early Mahdist Period, 1885-89 \\ Iris Seri-Hersch
}

\section{- To cite this version:}

Iris Seri-Hersch. Confronting a Christian Neighbor: Sudanese Representations of Ethiopia in the Early Mahdist Period, 1885-89. International Journal of Middle East Studies, 2009, 41 (2), pp.247267. 10.1017/S0020743809090655. halshs-00489574

\section{HAL Id: halshs-00489574 \\ https://shs.hal.science/halshs-00489574}

Submitted on 5 Jun 2010

HAL is a multi-disciplinary open access archive for the deposit and dissemination of scientific research documents, whether they are published or not. The documents may come from teaching and research institutions in France or abroad, or from public or private research centers.
L'archive ouverte pluridisciplinaire HAL, est destinée au dépôt et à la diffusion de documents scientifiques de niveau recherche, publiés ou non, émanant des établissements d'enseignement et de recherche français ou étrangers, des laboratoires publics ou privés. 


\title{
Iris Seri-Hersch
}

\author{
CONFRONTING A CHRISTIAN NEIGHBOR: \\ SUDANESE REPRESENTATIONS OF ETHIOPIA \\ IN THE EARLY MAHDIST PERIOD, 1885-89
}

Al-Zaki ordered [his men] to bring it [Yohannes's corpse] out of the box, and it was brought out. He ordered [them] to cut his head off and hang it on a spear. So they cut his head off and hung it on a spear. The anșār were delighted and rejoiced at this victory, which would stand as an embroidery on the Muslim armies' flags for centuries to come. ${ }^{1}$

This is how Isma il bin 'Abd al-Qadir, a Mahdist chronicler of late 19th-century Sudan, gave a broad Islamic significance to the defeat of Ethiopian armies by Mahdist forces at al-Qallabat in March 1889. Culminating in the death of Emperor Yohannes IV, the four-year confrontation between Mahdist Sudan and Christian Ethiopia (1885-89) had repercussions that transcended the local setting, reaching far into the intertwined history of Sudan, Ethiopia, and European imperialism in the Nile Valley and Red Sea regions.

On the historiographical scene, Sudanese-Ethiopian relations in the early Mahdist period have drawn little attention. Scarce studies have produced political and military histories. ${ }^{2}$ I suggest examining Mahdist conceptions and attitudes toward Christian Ethiopia through an approach that highlights representations. Two distinct meanings of the term are particularly relevant for our study: representations as an object and representations as a tool of history. ${ }^{3}$ This article addresses the following key issues: How did a Mahdist scholar represent Sudanese-Ethiopian relations and to what ends? Were his conceptions shared by the Sudanese ruling elite? How far do they reflect actual practice in interacting with Christian Ethiopia?

Applying these questions to the years 1885-89, I focus on the border zone spreading from the Atbara River to the Blue Nile. This area appears as a major theater of MahdistEthiopian collision in most primary and secondary sources. ${ }^{4}$ In addition to 'Abd alQadir's writings, I have consulted Sudanese archives at the National Records Office in Khartoum and accounts of foreigners who traveled or lived in Sudan and Ethiopia during the Mahdist period, ${ }^{5}$ as well as scholarly works by historians, notably, those of Sudanists Muhammad Ibrahim Abu Salim ${ }^{6}$ and Muhammad Sa id al-Qaddal.

FROM REVOLUTIONARY MILLENARIANISM TO STATE BUILDING

In Sudan, the revolution led by the Mahdist movement between 1881 and 1885 ended sixty years of Turco-Egyptian rule. Its leader-Muhammad Ahmad bin 'Abdallah, who Iris Seri-Hersch is a PhD candidate at the Institut de Recherches et d'Etudes sur le Monde Arabe et Musulman, University of Provence, Aix-en-Provence, France; e-mail: iris_hersch@yahoo.ca

(C) 2009 Cambridge University Press 0020-7438/09 $\$ 15.00$ 
claimed to be al-mahdī al-muntazar ${ }^{7}$ — quickly achieved political and military victories against the established regime thanks to wide support from various groups within Sudanese society. The Turco-Egyptian government was resented by many because of its foreign nature, its reliance on Christian officials such as Samuel Baker and Charles Gordon, its oppressive fiscal policies, its attempts to suppress the slave trade, and its efforts to impose Azharite orthodoxy in Sudan. ${ }^{8}$

The years 1881-85 can be seen as the formative period of the Mahdist state: the revolutionary movement expanded its control over vast territories while being transformed into a state apparatus. Khartoum's conquest in January 1885 made the Mahdist capital move from a rather peripheral zone (Jabal Qadir) to the very power center of Turco-Egyptian rule. In addition to the Mahdiyya's growing institutionalization, which was salient in the administrative, military, financial, and judicial fields, all decision-making powers were concentrated in the hands of the Mahdi. Indeed, the latter abolished the existing Sufi orders and the Islamic traditional schools of law (madhähib), recognizing the sunna, the Qur'an, and ilhām (prophetical inspiration) as the only sources for Mahdist law. ${ }^{9}$

Muhammad Ahmad's death in June 1885 caused a momentary crisis in his community, which was resolved by the designation of 'Abdullahi al-Ta'aishi as his successor. During the first part of his rule (1885-89), Khalifa 'Abdullahi ${ }^{10}$ had to face various internal and external challenges that had a significant impact on later evolutions in Mahdist Sudan. Among numerous opposition forces, the ashrä $f$ (relatives and supporters of the Mahdi) led by Muhammad Sharif represented the greatest threat to the khalifa's rule. Other insurrection movements erupted in Darfur and on the Sudanese-Ethiopian border, the discourse of which often had messianic overtones. Besides these political menaces, a destructive famine ravaged the Sudan in 1889-90, which had dramatic social, demographic, and economic effects. ${ }^{11}$

In the external arena, the Mahdist state maintained tense relations with two of its immediate neighbors: Egypt and Ethiopia. The former constituted the primary target of Mahdist territorial expansion. Although the Mahdi had already planned to attack his northern enemy, the campaign was postponed until 1889 on the grounds of physical and political difficulties. ${ }^{12}$ The Sudanese forces were totally overwhelmed by AngloEgyptian troops at the famous battle of Tushki (3 August 1889), which put an end to Mahdist ambitions toward Egypt.

\section{CONSOLIDATING AN IMPERIAL ORDER}

Whereas Khalifa 'Abdullahi completed the transformation of the Mahdist movement into a state structure, negusä nägäst ${ }^{13}$ (king of kings) Yohannes IV (1872-89) pursued the imperial unification of Ethiopia that had been initiated by his predecessor Tewodros II (1855-68). Rather than uncompromising centralization, Yohannes IV opted for a policy of "controlled regionalism,"14 which led to the submission of 'Adal of Gojjam (October 1874) and Menelik of Shoa (March 1878), two prominent local commanders. The process of imperial unification had a significant religious dimension, which was reflected in mass Christianization policies.

In May-June 1878, Yohannes IV convened a council at Boru Meda, where the Tewahedo creed was proclaimed official doctrine while Christian heretical sects were harshly 
condemned. ${ }^{15}$ The imperial edict did not merely address Ethiopian Christians. Muslims, pagans, Gallas, and Jews were called to convert lest they be banished. ${ }^{16}$ Two famous Muslim leaders of the Wallo region adopted Christianity-Amade Liban (known as Abba Wataw) and Muhammad 'Ali. Whereas the former was baptized Hayla Maryam and obtained the title of dajjazmach, the latter became ras Mika'el and was given control over a large part of the Wallo central highlands. ${ }^{17}$ Adhering to the official religion was indeed a necessary condition for advancement within the Ethiopian political and military hierarchy.

Yohannes IV's Christianization policy included building numerous churches in Wallo, excluding Muslims from the city of Aksum, and confiscating Islamic books. ${ }^{18}$ In quantitative terms, 50,000 Muslims, 20,000 "pagans," and half a million Gallas had supposedly been baptized by $1880 .{ }^{19}$ The reactions of Wallo Muslims to the emperor's evangelist measures varied. Although most political leaders converted in order to keep their posts, some secretly continued practicing Islam. Others migrated south or west toward Sudan. ${ }^{20}$ Military resistance was carried out on several occasions. ${ }^{21}$

In the external arena, Ethiopia's unification was threatened by both European and Egyptian protagonists. The opening of the Suez Canal (1869) attracted European powers to the Red Sea, and khedive Isma il (1863-79) directed his expansionist efforts toward Sudan and Ethiopia. He occupied the Bogos territory (also known as Senhit, see Figure 1) in 1872 and the city of Harar three years later. Yohannes IV managed to crush Turco-Egyptian ambitions by winning two decisive battles at Gundet and Gura (187576). ${ }^{22}$ However, both France and Italy set foot on Ethiopia's eastern coast, in Obock and Assab, respectively, contemplating a future progression into the interior.

By the late 1870 s, the emperor's power had reached a climax: potential internal rivals had been subdued, many of his Muslim subjects had been Christianized, and the Egyptian adversary had been defeated. Yet the early 1880s witnessed strategic changes that deeply affected Ethiopia. The Mahdist revolution and the simultaneous occupation of Egypt by the British created a new set of dynamics, challenging Yohannes IV's political and personal survival. Weakened Egypt was replaced by a militant Mahdist state as Ethiopia's immediate neighbor. The increasing British presence in the Nile Valley and the Red Sea eased Italian penetration into eastern Ethiopia. ${ }^{23}$ The year 1885 was a turning point in the emperor's career: while Italy took control of the Massawa port town with British tacit agreement (3 February 1885), an armed conflict broke out between Sudan and Ethiopia. Regional commander Menelik's growing insubordination was a third factor weakening Yohannes IV's uncertain political position. ${ }^{24}$

A CONFRONTATION ENTANGLED IN EUROPEAN IMPERIAL PROCESSES

Political and military tensions between Sudan and Ethiopia were catalyzed by the Hewett Treaty that Great Britain and Ethiopia signed on 3 June 1884. Yohannes IV committed himself to assist the evacuation of Turco-Egyptian troops stationed on his western border. In return, he regained the Bogos territory and was promised free transit of all goods through Massawa, an easy dispatch of bishops from Alexandria, and British arbitration in case of conflicts involving the khedive. ${ }^{25}$ Hence, Ethiopian 


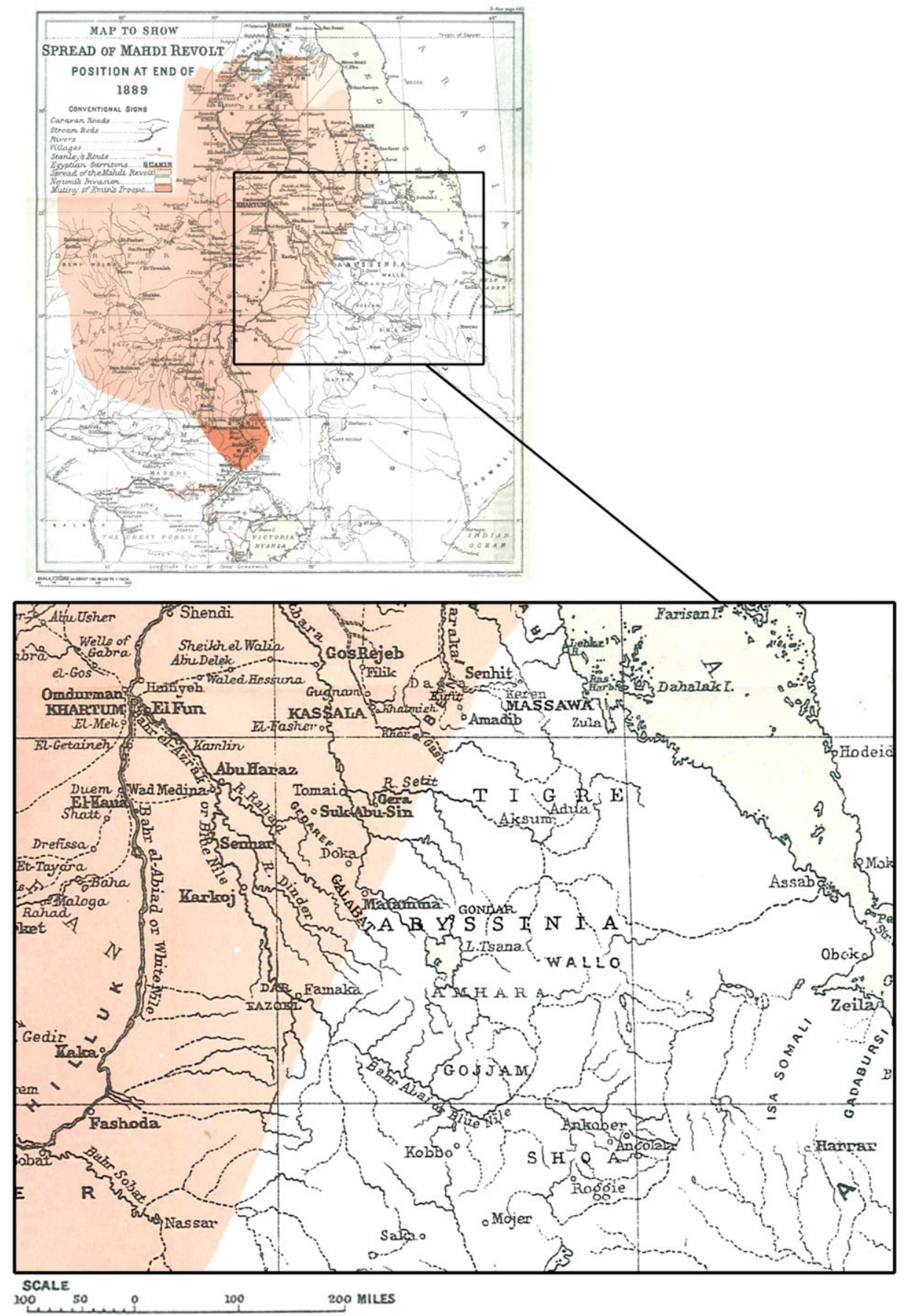

FIGURE 1. The Sudanese-Ethiopian border zone in 1889. Adapted from Mahdiism and the Egyptian Sudan. ${ }^{26}$ [A color version of this figure can be viewed online at journals.cambridge.org/mes] 
soldiers found themselves fighting against Mahdist forces in Kassala and in an area between the Atbara River and the Blue Nile. Three major Turco-Egyptian centers located in that zone fell under Mahdist control in 1884-85: al-Qadarif, al-Qallabat, and al-Jira. ${ }^{27}$

From March 1885, bidirectional raids across the Sudanese-Ethiopian border significantly increased. Local Mahdist commander Muhammad wad Arbab was killed during an Ethiopian assault on al-Qallabat in January 1887, which caused the death of thousands of ansār. ${ }^{28}$ The next Mahdist governor of al-Qallabat, Yunis al-Dikaym, openly provoked Ethiopia when he arrested a caravan of Ethiopian merchants, sending them to Omdurman as if they were war captives. Intending to strengthen Mahdist positions on the eastern front, Khalifa 'Abdullahi ordered amir Hamdan Abu 'Anja to quit the Nuba Mountains and join al-Dikaym. Shortly after his arrival at al-Qallabat (early December 1887), political and religious troubles engendered tensions between the two commanders. ${ }^{29}$ Al-Dikaym was eventually recalled to Omdurman and replaced by Abu 'Anja.

During his one-year tenure, Abu 'Anja organized two great campaigns into Ethiopian territory. The first was directed against Takla-Haymanot, ${ }^{30}$ whose troops were defeated in Dambiya in January 1888. After sacking the ancient imperial capital of Gondar, the Sudanese forces quickly returned to al-Qallabat. Although this expedition constitutes the furthest Mahdist territorial expansion into Ethiopia, it was not pursued because of geographic, logistic, strategic, and religious factors. ${ }^{31}$ The second was when Abu 'Anja led his troops to the Balesa province, east of Lake Tana in June 1888. Heavy rains nevertheless constrained the anșār, who retreated after a short while.

The amir's sudden death in January 1889 provoked a temporary confusion about his succession. A Mandala client of the Ta'aishi tribe, al-Zaki Tamal, was eventually appointed. Meanwhile, Yohannes IV prepared his armies to crush the Mahdist camp. He launched an attack on al-Qallabat on 9 March 1889, during which his troops managed to penetrate the town. The anșār were on the verge of being overwhelmed when the emperor was hit by a bullet and collapsed. Horrified, the Ethiopian soldiers took flight, and victory turned into defeat. ${ }^{32}$ Considerable booty fell into Mahdist hands, including many objects and clothes that had belonged to Yohannes IV.

The battle of al-Qallabat marked a peak in the conflict between Mahdist Sudan and Ethiopia. During the 1890s, relations between the two states gradually improved until a peace agreement was reached in $1897 .^{33}$

In spite of its limited territorial scope, the 1885-89 confrontation bore some major strategic implications on the regional level. First, Yohannes IV's death meant the end of Tigre as the political center of Ethiopia. Power shifted to Shoa as Menelik seized the imperial throne and espoused a conciliatory policy toward Sudan. ${ }^{34}$ Second, Italian imperialist ambitions progressed thanks to the absence of both the emperor and his vassal Alula from Ethiopia's eastern front. Promptly formalized through the Wichale Treaty (2 May 1889), Italian expansion into northeastern Ethiopia led to the creation of the colony of Eritrea (1 January 1890). Thus, Italy can be held as the regional actor that most benefited from the Sudanese-Ethiopian conflict. Whereas Ethiopia experienced serious territorial amputation, Mahdist Sudan found itself frontally challenged by the Italian power. ${ }^{35}$ 
THE TIRAZ: A LITERARY EMBROIDERY OFFERED TO KHALIFA

'A B D ULLAH I

The Sudanese-Ethiopian conflict seems to have been of great importance to the khalifa, who wanted an official version of the facts to be written and distributed among his literate subjects. The work was left to Isma il bin 'Abd al-Qadir (1844-97), the author of a book about the Mahdi's life and the Mahdiyya's early years. ${ }^{36}$ His chronicle was completed less than three months after the battle of al-Qallabat under the title Al-Tiraz al-Manqush bi-Bushra Qatl Yuhanna Malik al-Hubush (The Embroidery Inscribed with the Good News of the Slaying of Yohannes, King of the Ethiopians) ${ }^{37}$ It was given wide diffusion throughout Sudan.

Born in the provincial capital of El Obeid, 'Abd al-Qadir studied at al-Azhar for twelve years and was later appointed mufti of Kordofan under Turco-Egyptian rule. Although the reasons why he joined the Mahdist movement in September 1882 remain uncertain, it seems that he settled down in Omdurman after the fall of Khartoum (January 1885). ${ }^{38}$ 'Abd al-Qadir attained a high position within the judicial and religious system of the Mahdist state as a qadi and 'alim enjoying a close relationship with the khalifa.

However, his career was abruptly interrupted by his banishment to al-Rajjaf (upper White Nile) in August 1893, where he died a few years later. ${ }^{39}$ The khalifa ordered the burning of all copies of his books, which included several scientific, historical, and poetical writings.

How should we understand this decision, as the Tiraz praises 'Abdullahi in multiple ways? At a time when Menelik II tried to establish friendly relations with his western neighbor, the head of the Mahdist state possibly sought to get rid of any writing associated with anti-Ethiopian propaganda. In addition, the elimination of a chronicle that stressed the role of men other than the khalifa contributed to consolidate the latter's personal grip on political power. ${ }^{40}$

In a historiographical perspective, the Tiraz constitutes a primary source of major importance for the study of Sudanese-Ethiopian relations. It is chronologically the first work depicting the 1885-89 conflict and counts among the very few narrative-oriented sources that espouse a Mahdist viewpoint on Sudan. We know its existence thanks to the kātib Muhammad Ahmad Hashim, who secretly conserved one copy of the Tiraz despite the khalifa's order to destroy all of 'Abd al-Qadir's writings. ${ }^{41}$

Given that the chronicler did not personally witness most of the events he relates, what were his sources? He relied on his book about the early Mahdiyya and on various proclamations from the Mahdi and the khalifa, as well as on a small number of letters exchanged between the khalifa and Mahdist commanders posted at al-Qallabat. However, he privileged oral accounts of direct witnesses, such as the qadi al-Islam Ahmad 'Ali. ${ }^{42}$

\section{SUBORDINATING HISTORY TO PANEGYRIC ENDS}

Written in literary Arabic and comprising numerous stylistic devices, the Tiraz is structured according to the following scheme:

\footnotetext{
Preamble Motives, objectives, and contents of the Tiraz.

Preface Legitimization and glorification of Khalifa 'Abdullahi

1st chapter Yunis al-Dikaym's command (Spring 1887-January 1888)
} 
2nd chapter Hamdan Abu 'Anja's command (December 1887-January 1889)

3rd chapter Al-Zaki Tamal's command (February-March 1889)

Conclusion Mahdist operations in Darfur, Equatoria, Suakin; military plan to conquer Egypt

Throughout his book, 'Abd al-Qadir emphasizes Mahdist military victories not only against Ethiopia but also in Darfur, Equatoria, Egypt, and on the Red Sea coast. The glorification and idealization of these successes aimed at consolidating the khalifa's political and religious legitimacy, which was largely questioned by the ashrāf and other opposition forces. The Tiraz depicts the Mahdi's successor as a perfect model of statesman, military commander, and pious figure. 'Abd al-Qadir's triumphal and optimistic tone stems from the particular historical circumstances in which he wrote the chronicle: after the Mahdist victories against Abu Jummayza ${ }^{43}$ in Darfur and the Ethiopians at al-Qallabat (respectively, on 22 February and 9 March 1889) but before the anșār's total failure at Tushki (3 August 1889).

As a panegyric work, how is the Tiraz connected to historical reality? 'Abd al-Qadir's objective is clearly stated in the preamble: to convince the world of the Mahdiyya's ultimate truth. This assumed ahistorical approach remains consistent throughout the entire narrative. The author does not hesitate to alter certain aspects of historical reality to achieve his panegyric and persuasive ends. Some facts and processes are deformed and others are simply omitted. For instance, several expeditions into Ethiopian territory are related in an incorrect chronological order, and some of their commanders are not rightly named. ${ }^{44}$ Among some crucial events that are silenced, let us mention the episode of al-Nabi ' $\mathrm{Isa},{ }^{45}$ the quarrel it provoked between the amirs al-Dikaym and Abu 'Anja, the activities of the ashräf, Mahdist military defeats against Ethiopian forces (such as the one in Kufit in September 1885), and the intensive epistolary exchanges between various Sudanese and Ethiopian leaders. ${ }^{46}$

How are we to explain these multiple deformations and omissions? What can they teach about 'Abd al-Qadir's political, ideological, and religious orientations? First, specific deformations could result from unintentional human errors. Second, particularly threatening facts are omitted in order not to undermine the khalifa's position as the Mahdi's sole legitimate successor. ${ }^{47}$ Third, 'Abd al-Qadir distorts or leaves out events that could endanger the Mahdiyya's image as a united and victorious movement. Finally, his efforts to describe Sudanese-Ethiopian relations in an absolutely Manichean manner discard any complexity or nuances. ${ }^{48}$ Hence, his position within the Mahdist state seems to suit Abu Salim's model: as a historian employed by the regime, he had to document the events in a way that glorified the government and legitimated the existing system. ${ }^{49}$

Even though the Tiraz is not reliable from a classical historical stance, it becomes an extremely useful source for the study of representations when confronted with various historical documents.

THE SUDANESE-ETHIOPIAN CONFLICT: A VICTORY OF ISLAM OVER CHRISTIANITY

The Tiraz narrates the Sudanese-Ethiopian confrontation from a Mahdist perspective, which implies a sharp distinction between the anșār and the kuffā $r$ (unbelievers including non-Mahdist Muslims). ${ }^{50}$ Contrary to al-Qaddal's assumption, the infidels were not 
perceived as a homogeneous group of "Turks" 51 : the Ethiopians were actually singularized among other unbelievers. 'Abd al-Qadir names them kuffā $r$ or 'abadat al-salīb (cross worshippers) in some cases, but he mostly uses the more specific and less religiously connoted term of Habasha. ${ }^{52}$

His book represents Sudanese-Ethiopian relations through three important stages. The first one consists of justifying Mahdist warfare against Ethiopia from 1887 to 1889. For this purpose, the author interprets a prophetical hadith in the light of events that occurred in Sudan before the Mahdist revolution. The Prophet's saying to the Muslims "utrukū al-Habasha mā tarakūkum" (leave the Ethiopians alone as long as they leave you alone) was relevant in early Muslim history, a time when-according to 'Abd al-Qadir-Ethiopia was not a priority target of Islamic expansion. However, strategic conditions had greatly changed by the late 19th century. Corrupted Turco-Egyptian rulers let Ethiopian unbelievers invade the "land of Islam" (Sudan), build churches, and collect taxes from its inhabitants. ${ }^{53}$ In addition, Christian ruler Yohannes IV refused to submit to God and unjustly killed disciples of the Mahdi ${ }^{54}$ Relying on these arguments, 'Abd al-Qadir claims the fight against the Ethiopians to be fully licit. It is not only a right but a compulsory duty falling to the Muslim community as a whole.

The second stage pertains to the attitude that the Mahdist state actually endorsed toward Ethiopia. A phase of verbal persuasion, materialized by two warning letters addressed by the khalifa to the emperor in 1887, is followed by a process of physical coercion. In 'Abd al-Qadir's perspective, warfare constitutes the main instrument of Sudanese policy toward Ethiopia. As a holy war (jihad), it implies the fusion of military and religious aspects inherent to Mahdist ideology. Military actions and procedures, as well as victories and defeats, constantly express the will of God. The image of a tight and compact line of anșär is crucial in the Tiraz, for it is associated with both a military and a spiritual posture..$^{5}$

The book is dominated by a Manichean representation of the Sudanese-Ethiopian conflict, which is attained through various literary and narrative processes. Hence, the battle of al-Qallabat (March 1889) is depicted with the help of an elaborate metaphorical and symbolic language. Whereas the rapid progression of the Ethiopians is successively compared to a waterfall and a cloud of locusts, the Mahdists are evoked through their superior moral qualities: they are firmly determined to fight and die for the cause of Islam. ${ }^{56}$ The gap between victors and losers is mostly stressed after the cessation of hostilities. Countless Ethiopian corpses strew the ground; the survivors cowardly pretend that their king merely suffers from injuries, although a deadly bullet actually hit him. By contrast, the fallen anșār are represented as a small group of martyrs (shuhada ${ }^{\text {) }}$ ) honored by God. Whereas their blood looks like gold on their necks, Ethiopian blood soils the Atbara River and pollutes its water.

'Abd al-Qadir stresses the conflict's dramatic metaphysical implications by exploring semantic fields of terms such as $n \bar{a} r$ (fire) and zulma (darkness). As the Ethiopian troops move toward al-Qallabat, they are identified with bad fate and hell:

They [the Ethiopians] started lighting fires to remove the grass and the trees so that they could get through these abrupt places. I say: lighting fires masked a bad omen, which God realized in this world by burning them with the fire coming from firearms shot by the ansār. The fire of beyond is most intense! Accompanied by night fires lit to roast the food of the Ethiopian army, these fires 
could be seen from a three-day distance because of the intensity of their flames, which rose high into the sky [my emphasis throughout]. ${ }^{57}$

An immediate connection between the material and eschatological worlds appears as fighting between the Mahdists and the Ethiopians intensifies. The combination of firearm smoke, clouds of dust, and hand-to-hand fights between the two armies creates a particular type of apocalyptical darkness. 'Abd al-Qadir also emphasizes the divine nature of Mahdist struggle against Ethiopia by describing miracles that occurred during the battle of al-Qallabat. Mentioning these wonders ${ }^{58}$ contributes to the depiction of the conflict as a victory of Islam over Christianity.

The third stage relates to the outcome of Sudanese jihadist policy toward Ethiopia, which perfectly fits into 'Abd al-Qadir's ideological reasoning: Yohannes IV dies on the battlefield. Both the causes and the meaning of his death are interpreted in such a way as to crystallize a double lesson in the reader's mind: Mahdist victory against Christian infidels is inevitable, for it expresses God's will, but it is also the work of Khalifa 'Abdullahi. The chronicler explains the emperor's death by his exaggerated self-pride and hostile attitude toward Muslims. Its meaning is exceptional on several grounds. It not only eliminated a great threat to Islam, but it also counts among the most important conquests in Muslim history. According to 'Abd al-Qadir, the death of a Christian Ethiopian emperor at the hands of Muslim forces was hitherto unseen in the history of interactions between Ethiopia and the Islamic world. Moreover, it occurred — thanks to divine will—during Khalifa 'Abdullahi's reign. ${ }^{59}$ At the end of the battle, the anșār deal with Yohannes IV's corpse in a manner that strengthens the double message. The objects and clothes covering the body symbolize the Christian religion and the sybarite tendencies of the Ethiopian king: a golden cross, a matab (religious neck ribbon), ${ }^{60}$ a gem-decorated crown, and embroidered garments. They are sent to Omdurman as a material evidence of Yohannes IV's scornful attitude toward God. As the most central war trophy of the Sudanese-Ethiopian conflict, the emperor's head is cut off and brought to the khalifa with heads of other Ethiopian commanders. In this way, the bloody message not only announces victory but also grants it to the head of the Mahdist state. ${ }^{61}$

My analysis has shown that the Tiraz celebrates the victory of Mahdist Islam over Christianity in the shape of a panegyric dedicated to Khalifa 'Abdullahi. Sudanese policy toward Ethiopia bears no ambiguity: as a Christian entity that has dared to attack the frontiers of Islam, Ethiopia deserves to sustain the wrath of Mahdist jihad. However, was this perspective widely shared among the Sudanese ruling elite? If this apparently rigid logic framed their policies, what did it mean in practice and how was it legitimized?

\section{THE LIMITS OF A UNIVERSAL MISSION}

Depicted in various primary and secondary sources, Mahdist attitudes ${ }^{62}$ toward Ethiopia were much less obvious and linear than in 'Abd al-Qadir's work. Their complexity resides in the gap between theory and practice but more fundamentally in the definition of Mahdist ideology on the Ethiopian issue. How did Sudanese leaders conceive of the scope of the Mahdist mission? Should it be limited to the struggle against Turco-Egyptian domination or be extended to other parts of the world? 
Both historians and contemporaries of the Mahdiyya agree that the ambitions of the Mahdist revolution transcended the Sudanese arena. Whereas some scholars restrain its scope to the Islamic world, others extend it to the whole of humanity. ${ }^{63}$ However, the distinction between these two conceptions is not clear-cut. We should examine how the Mahdist elites perceived the external world before formulating any hypothesis.

Two elements must then be stressed. First, the world lying outside Sudan was grasped in theological rather than geographical terms. Anyone who did not accept Muhammad Ahmad's divine mission was considered an infidel. Second, the Mahdi's horizon was quite narrow, for it was limited to Muslim countries whose existence he was aware of. ${ }^{64}$ Like his predecessor, the khalifa sent letters to Muslim leaders in an attempt to convince them to submit to the Mahdiyya, yet he also included non-Muslim states such as Ethiopia and Britain. ${ }^{65}$ Expansionist efforts were abandoned after the defeat at Tushki and the great famine that ravaged Sudan in 1889-90. Therefore, Mahdist ambitions significantly evolved according to political, military, and economic circumstances. Without being the main prey of the Sudanese appetite, Ethiopia counted among a number of regional actors whose existence the doctrine of the Mahdiyya could not easily accommodate.

\section{THE AMBIGUITY OF THE JIHAD CONCEPT}

The term "jihad" is frequently used to describe both the ideology and the foreign policy of the Mahdist state. What does this concept mean in the particular historical context of Sudanese-Ethiopian relations? Numerous scholars agree on the conditions that propelled the use of jihad. Warfare followed the failure of persuasive efforts attempting to convert an area or state to Mahdist Islam. However, what precisely were the ends of this jihad? Although some historians see it as an instrument of forced conversions, others view it as a means to punish the unbelievers or subjugate them through enslavement. ${ }^{66}$ Jihad was also employed to fight against foreign rule (embodied by the Turco-Egyptian regime) or prevent unbelievers from invading the land of Islam. ${ }^{67}$ Abu Shouk stresses an interesting economic function. Under the banner of jihad, the Mahdist state often massacred people considered as infidels (Muslims or not) and confiscated their property. This state booty was then appropriated by the public treasury (bayt al-māl). ${ }^{68}$ Whatever its objectives, Mahdist jihad always conjured up a clash between the God led ansā $r$ - the only possessors of divine truth - and a mass of unbelievers. Therefore, jihad pertains to the ideological representation of a struggle whose goals could vary. Warfare is made holy by the ways in which it is legitimized rather than by its specific ends.

Addressing the Sudanese-Ethiopian military confrontation, should we see jihad as the main cause of conflict or merely as a rhetorical instrument for its legitimization? A few historians espouse a view similar to 'Abd al-Qadir's by identifying the jihadist orientation of the Mahdist state as a central explanatory factor. Because Ethiopia belonged to dār $a l$-harb, it was automatically the target of Mahdist attack. The religious obstacle between the two countries counted among the principal reasons underlying the conflict. ${ }^{69}$

Conversely, many scholars depart from the jihadist perspective by suggesting historical, political, military, and economic motives. For some of them, the conflict has historical roots that can be traced to the Funj Sultanate (1504-1821). ${ }^{70}$ This explanation seems particularly relevant when taking into account the works of Merid Wolde Aregay, Sergew Hable Selassie, and Mordechai Abir. They emphasize the persistence of certain 
sources of tension between the Sudanese and Ethiopian entities during the Funj and Turco-Egyptian periods: border-drawing issues, slave raids, and political support of rebels from each side. ${ }^{71}$ Political and military dynamics of clash included activities of local landlords in the border zone, internal rivalries, the khalifa's willingness to keep his armies busy far from the capital, and the application of the Hewett Treaty, as well as Egyptian and British efforts to foster Ethiopian hostility toward Sudan. ${ }^{72}$ Economic motives certainly greased the mechanism of conflict: opportunities to capture human and material booty in cross-border raids were enhanced by the commercial and strategic importance of al-Qallabat. ${ }^{73}$ Discussing the origins of the Sudanese-Ethiopian confrontation allows us to relativize the role of jihad as the main catalyst of Mahdist policy toward its neighbor. We should consider it a legitimizing device rather than as a frozen, inflexible policy.

\section{THE HERITAGE OF EARLY MUSLIM-AKSUMITE CONTACTS}

Although jihad served as a general framework for legitimizing Mahdist policies, other instruments were more precisely adapted to the Ethiopian case. The Mahdist elites used various prophetical references to make their attitudes acceptable to Sudanese or even Ethiopian sensibilities. An important tool consisted of reactivating the ambivalent heritage resulting from the first contacts between Muslims and the Kingdom of Aksum.

Facing a hostile environment, the emerging Muslim community found refuge at the court of negus Adriaz in $615 .^{74}$ The Quraysh leaders of Mecca hostile to Muhammad sent a delegation to Aksum in order to ask the return of the refugees to Arabia. At the head of the exiled sahāba, Ja far bin Abu Talib (Muhammad's cousin) successfully presented Islam as a form of Christianity in order to convince the negus to continue granting asylum to the Muslims. ${ }^{75}$ Whereas a minority of refugees joined the Prophet on his hijra to Yathrib (subsequently renamed Medina), most of them remained in Aksum until the Muslim conquest of Mecca (631).

This historical plinth fed two great traditions within Islamic thought. The first one relies on a 9th-century hadith, according to which the Prophet had ordered his disciples: "Let the Ethiopians alone as long as they leave you alone" (utrukū al-Habasha $m \bar{a}$ tarakükum). ${ }^{76}$ This saying is interpreted as a gesture of gratefulness for the assistance Ethiopia granted to the Muslims at a critical moment of their history. During the Middle Ages, a rich literature developed on the legal status of Ethiopia. Some Muslim jurists nuanced the traditional distinction between dār al-Islām and dār al-harb by defining intermediary stages called $d \bar{a} r$ al-' $a h d$ (abode of pact) and dār al-sulh (abode of conciliation). ${ }^{77}$ These statuses were attributed to territories enjoying a temporary agreement with the abode of Islam. However, several areas were exempted from jihad without any accord with Islam. Grouped under the name dār al-hiyād (abode of neutrality), such exceptional cases were justified by doctrinal or practical motives. They included Ethiopia, Nubia, Cyprus, and the Turks' land. ${ }^{78}$ In this regard, it is crucial to emphasize that their position was not chosen but rather imposed by Islam:

... [U]nder [a] legal system which regards all countries as inherently hostile save those which have obtained security by Islam's consent, only those states which Islam agreed to spare from the jihad might be regarded as neutral. Strictly speaking, such states were not neutral, in the sense of 
the modern law of nations, which recognizes the right of a state to declare [its] neutrality toward two or more belligerent powers; these states were neutralized states, that is, their neutrality was guaranteed by the powers, including the belligerent power or powers themselves [my emphasis]. ${ }^{79}$

Could this tolerant tradition toward Ethiopia explain the fact that the Muslims refrained from invading it during the first two centuries of Islam, or is the famous hadith a later fabrication meant to justify the incapacity of Islam to conquer Ethiopia? Most historians support the second hypothesis. In early Islamic times, Arabs' unsophisticated navigation techniques thwarted invasion of Ethiopia from the sea. The country's mountains constituted a second natural barrier to potential invaders. ${ }^{80}$ Moreover, the relative poverty of the Aksumite kingdom made it less attractive than the wealthy Byzantine and Sassanid empires. Hence, the fact that Ethiopia remained untouched by Muslim forces for centuries, combined with the prophetical hadith (utrukū al-Habasha mā tarakūkum), led Muslim thinkers to define a particular status for Ethiopia ( $\dot{d a} r$ al-hiya $\bar{d})$.

A second tradition developed out of Muslim-Aksumite contacts, which also shaped the ways in which the Muslim world dealt with Ethiopia. It is rooted in a story reported by al-Tabari, according to which the Prophet sent a letter to the Aksumite negus, calling upon him to adopt Islam. Medieval Islamic sources state that al-Najashi put the letter on his head, descended from his throne, and pronounced the shahäda as a sign of submission to Islam. He then sent a message to the Prophet in order to confirm his conversion. ${ }^{81} \mathrm{He}$ even provided the Muslims of Medina with military support. When the negus died, "the Prophet prayed for him and implored God to forgive his sins." 82 Contrary to this type of Islamic literature, Western and Ethiopian modern historiographies deny al-Najashi's conversion to Islam.

Stressing Ethiopia's submission, this Islamic tradition was later used to legitimize intolerant attitudes toward the Christian kingdom. For example, in 16th-century Ethiopia, where coastal areas had been gradually Islamized since the end of the 10th century, a local Muslim leader initiated a militant campaign against the Christian Solomonic Kingdom. ${ }^{83}$ Imam Ahmad bin Ibrahim (nicknamed Grañ in Amharic, which means "the left-handed") was motivated by a jihadist ideal to compel Ethiopia to enter dār al-Islàm. Between 1527 and 1543, his Muslim armies occupied the highlands' main cities, burnt churches and monasteries, and converted a large number of Christians by force. Imam Ahmad managed to extend his power to three quarters of the Ethiopian territory. ${ }^{84}$ His attempt at Islamization ended when Emperor Galawdewos (1540-59) defeated him near Lake Tana with Portuguese support.

Stressing the illegitimacy of Christian Ethiopia as a political and religious entity, imam Ahmad's jihad broke with the cautious attitude Muslims had traditionally espoused toward the Christian kingdom. ${ }^{85}$ His militant project was closely connected to the tradition that denigrated Ethiopia's Christian identity through an emphasis on the negus's conversion to Islam.

\section{AHDIST REVIVAL OF AN AMBIVALENT LEGACY}

How did the ruling elite of Mahdist Sudan reactivate the ambivalent legacy of early Muslim-Aksumite interactions? I address this question by analyzing letters sent to Emperor Yohannes IV by three central actors of the Mahdist state: the Mahdi, Khalifa 
'Abdullahi, and amir Hamdan Abu 'Anja. Answering a letter in which the emperor expresses his willingness to be informed of Sudanese intentions toward Ethiopia, the Mahdi affirms the authority of Islam over all other religions and strives to convince Yohannes IV to convert. He legitimizes his attitude on the basis of two principles. First, he appropriates the militant tradition whose premise is the conversion of the Aksumite negus to Islam. Second, he uses analogical reasoning, stating that because he is the Prophet's successor, Yohannes IV is al-Najashi's successor and thus has to act like him. The Mahdi offers no other alternative: "If you choose disobedience and prefer blindness to guidance and the right path, it will be your fault and the fault of your followers, for you will inevitably fall into our hands. We were promised the possession of the whole earth, of which you represent only a small part." ${ }^{86}$ In light of this clearly aggressive stance, we do not agree with Erlich when he asserts that the Mahdi's letter includes "both contradictory messages of ancient times." 87

Drawing from the precedent established by the Mahdi, the khalifa's attitude toward Ethiopia significantly evolved according to strategic, political, and military circumstances. A few months after his accession to power, he reactivated the tolerant tradition in order to restrain Uthman Diqna's ambitions in northern Ethiopia. He wrote to his commander:

We heard the news of your advance to Ethiopia.... Things should be arranged according to their importance and we have heard that the problems in Kassala are still unsettled . . . and so is the situation in [Suakin] . . . Do not attach great importance to the Ethiopian affair. . . . Leave the Ethiopians and do not enter their country now. ... Return to [Suakin]; that is what we want. ${ }^{88}$

The utruku al-Habasha tradition is less a cause for the khalifa's attitude than a legitimizing device. To the Mahdist leader, dealing with the Egyptians and the British seemed at that moment more urgent than escalating the conflict with Ethiopia. In 1887, the khalifa wrote two letters to Yohannes IV, whose comparison reflects a deep transformation of his attitude toward his eastern neighbor. In less than a year, political pragmatism was replaced by an uncompromising ideological religiosity.

The first letter was written after the Ethiopian attack on al-Qallabat (January 1887) and contains two levels of proposal. At the political level, the emperor can avoid a Mahdist attack by fulfilling three conditions set by the khalifa: returning Muslim war captives to Sudan, clarifying the position of Muslim "traitors" who took refuge in Ethiopia, and respecting the frontiers of the "land of Islam." 89 Satisfying such conditions would preserve the status quo between Sudan and Ethiopia. The second proposal pertains to the spiritual and ideological spheres. The khalifa calls upon Yohannes IV to convert to Mahdist Islam but in a very different way than that of the Mahdi eight months earlier. Rather than mentioning the Aksumite negus, he refers to a Qur'anic verse (3:64) enjoining the "people of the book" (ahl al-kitāb) to believe solely in Allah. If the emperor refuses, "the transgression of the borders [would lead to] disastrous consequences." 90 A Mahdist assault would result from an Ethiopian incursion beyond what was considered the Christian kingdom's border-but not from Yohannes IV's rejection of Islam. Later in his letter, the khalifa explicitly refers to the utruku al-Habasha hadith to justify the "fact" that the ansār refrained from fighting against Ethiopia. ${ }^{91}$ His attitude is perhaps purposefully ambivalent. On the one hand, he seems to espouse a militant approach when he calls the emperor to convert to Mahdist Islam. On the other hand, he suggests 
the possibility of a political agreement whose legitimization is rooted in the famous hadith.

The second letter he addressed to Yohannes IV does not show any sign of moderation or readiness to compromise. This can be partially explained by the changing balance of power between Sudan and Ethiopia. Toward the end of 1887, the khalifa was preoccupied by Ethiopian moves in the border zone and opted for a more offensive stance. While Abu 'Anja was joining forces with al-Dikaym in al-Qallabat (December 1887), the khalifa sent a hostile letter to his Ethiopian counterpart. It follows the logic previously espoused by the Mahdi, founded on Christian Ethiopia's illegitimacy. Mahdist raids (led by alDikaym in May-June 1887) are justified by the fact that the emperor did not respond to any of the Mahdi's and khalifa's injunctions. Unlike al-Najashi, the emperor refused to enter dār al-Isläm. That is why "the Muslims attacked [his] land, destroyed the houses, killed the men, burnt the churches and the big cities, outraged the women, and made the children orphans. They came back with great booty and God's satisfaction." 92 As an ultimate warning, this letter still allows Yohannes IV to change his mind and convert. However, if he persists in his disobedience, he should expect Ethiopia's total devastation at the hand of Mahdist forces. ${ }^{93}$ In contrast to the first letter, this one constantly evokes divine will as the catalyst of human decisions and actions. Its religious militant rhetoric does not allow room for political negotiations.

Such a militant attitude lasted until the emperor's death (10 March 1889). Abu 'Anja's reply to a peace proposal from the Ethiopian ruler (dated 25 December 1888) pushed the khalifa's logic to an extreme point. First, he introduces himself as "the commander of the armies of Islam [whose purpose is] to annihilate the vile unbelievers." 94 Second, he recalls the militant tradition that the Mahdi assumed before him, condemning the emperor's refusal to accept the Mahdist message. The inflexibility of his ideological posture is most salient when he mocks the peace proposal:

As of your request for peace while you remain infidel, it is unattainable. It is a sign of your mental weakness and lack of intellect. How stupid and ignorant you are! Do you want peace and fraternity without having adhered to the true religion? The book of God forbids this; therefore I cannot satisfy your request. If you want peace, say from the bottom of your heart: "I testify that there is no God but Allah and that Muhammad is his Messenger." For if not, we shall kill you, destroy your houses, make your children orphans—-with God's permission-[and] we shall take your goods as booty. ... ${ }^{95}$

This Manichean representation of Sudanese-Ethiopian relations evokes the kind of jihadist ideology we have described earlier. The Christian kingdom must imperatively choose between dār al-Islām and dār al-harb. Unlike the khalifa, Abu 'Anja explicitly asserts the nonexistence of any alternative deriving from the utruku al-Habasha hadith. According to al-Qaddal, this letter expresses a feeling of powerfulness created by the success of the Gondar campaign one year before. ${ }^{96}$ The emperor's peace proposal was interpreted as a sign of Ethiopian weakness, a conception that was not mistaken. ${ }^{97}$

Ruling Mahdist elites reactivated the ambivalent heritage of Muslim-Aksumite contacts in order to legitimize evolving policies toward their Christian neighbor. Varying regional strategic configurations made them oscillate between the two Muslim traditional attitudes vis-à-vis Ethiopia. 
PROPHETIC VISIONS

Besides the rather "theoretical" instrument of symbolic reactivation, a much more "practical" tool was used for legitimizing ends: prophetic visions (hadarāt nabawiyya). ${ }^{98}$ With regard to Ethiopian affairs, the khalifa resorted to such visions on two occasions. The first one (5 January 1888) occurred at a critical moment in Sudanese-Ethiopian relations: between the second letter that he addressed to Yohannes IV (mentioned previously) and Abu 'Anja's campaign to Gondar. Attached to a message sent to the amir, the vision granted him prophetic permission to attack Ethiopia. The khalifa depicts the Mahdist victory as if it had already taken place: "When prophetical authorization about the mentioned enemies [the Ethiopians] reached us, we ordered Hamdan Abu 'Anja and the anșa $r$ that are with him to raid them. They attacked them in the midst of their land and vanquished them with the help of God." 99 The vision ends with the proclamation of the takbir ("God is greatest") against Ethiopia, a symbol of God's all powerfulness, which no human weapon can oppose. Abu 'Anja started his campaign three days after the diffusion of this prophetic vision. The anșār defeated Takla-Haymanot's forces at Dambiya and pillaged Gondar, burning its many churches. ${ }^{100}$

The second hadra dates from April to May 1888 and addresses the Mahdist community as a whole. Its main objectives are to legitimize the khalifa's past domestic policies as well as his future foreign policies. The manner in which it deals with the Ethiopian issue reflects the strategic situation of Sudanese-Ethiopian relations: "The Prophet informed me in this vision that if the enemies of God, the Ethiopians, came to attack, their hands would be tied up to their necks and we would be victorious." 101 The khalifa was preoccupied with possible Ethiopian reprisals in response to Abu 'Anja's attacks. He sought to warn his subjects of such an eventuality, guaranteeing a defensive victory.

As a legitimizing device, prophetic visions had the advantage of irrefutability. Indeed, the bulk of the anșa $r$ could not doubt either their validity or their divine nature lest they undermine the khalifa's status as successor of the Mahdi. They could even be accused of denying the Prophet himself. Conversely, the reactivation of Muslim traditions toward Ethiopia presented an ambivalent character that exposed it to diverging interpretations and critiques. The process of legitimization was thus divided into two distinct parts. Whereas the word of the Prophet was meant to justify the khalifa's Ethiopian policy in Mahdist eyes, Muslim traditions were reactivated in the framework of a dialogue with the Ethiopian enemy.

\section{CONCLUSION}

In the first part of this article, I examined how the Tiraz depicts Sudanese-Ethiopian relations in powerful ideological and religious terms, using them as a "panegyrization" instrument. Both the chronicle's title and contents are devoid of any nuance or ambiguity.

Confronting it with various primary and secondary documents achieved two major results. First, the critical use of sources has led me to underline the Tiraz's fundamentally ahistorical nature. The gap between 'Abd al-Qadir's representations and a historically (re)constructed past reveals an implicit confrontation between two discursive systems: the persuasive ambition of a historian employed by the Mahdist regime on the one side and, on the other, my "truth" ambition as a historian in the early 21 st century. Second, 


\section{Iris Seri-Hersch}

replacing the Tiraz within a wider Mahdist perspective has prompted me to nuance Mahdist attitudes toward Ethiopia.

Although-or perhaps because-'Abd al-Qadir was summoned to write an official account of Sudanese-Ethiopian hostilities, his manuscript does not draw a comprehensive picture of either Mahdist conceptualizations or actual policies toward Christian Ethiopia. The Tiraz reflects selective dimensions of Mahdist positions on the Ethiopian issue, such as the utrukū al-Habasha hadith and the khalifa's two letters to Yohannes IV. However, even the mention of these items does not do justice to actual Mahdist attitudes: the hadith is interpreted in a fashion that can only justify warfare against the Christian empire; the letters' significance is minimized by their random appearance in the text.

The Tiraz's specific ideological framework masks a variety of factors underlying the Sudanese-Ethiopian conflict, including historical, political, military, and economic motives. Far from pretending that Mahdist leaders did not frequently resort to jihadist discourse, I argue that it should be recognized as a rhetorical instrument of legitimization rather than as the expression of a monolithic policy.

Focusing on representations, this study contributes to our understanding of limited aspects of Sudanese-Ethiopian relations in the early Mahdist period. We need further scholarly works discussing Ethiopian perspectives on the issue, examining various modes of exchange between the two countries, or evaluating the Mahdist-Ethiopian conflict's later repercussions with regard to the elaboration of Sudanese and Ethiopian national historiographies during the 20th century.

\section{NOTES}

Author's note: This article is based on a master's thesis entitled Le Soudan Mahdiste face à l'Abyssinie Chrétienne: Une Histoire de(s) Représentations (University of Provence, France, June 2007). My thanks to Professors Ghislaine Alleaume and Catherine Miller (IREMAM, Aix-en-Provence), Barbara Casciarri (CEDEJ, Khartoum), and the staff of the National Records Office in Khartoum. Unless noted, the translations are mine.

${ }^{1}$ Muhammad Ibrahim Abu Salim and Muhammad Sacid al-Qaddal, eds., Al-Harb al-Habashiyya alSudaniyya: 1885-1888 (The Ethiopian-Sudanese War) (Beirut: Dar al-Jil, 1991), critical edition of Isma ${ }^{\circ}$ il 'Abd al-Qadir al-Kurdufani, Al-Tiraz al-Manqush bi-Bushra Qatl Yuhanna Malik al-Hubush (The Embroidery Inscribed with the Good News of the Slaying of Yohannes, King of the Ethiopians) (Omdurman, Sudan: handwritten manuscript by the kātib Muhammad Ahmad Hashim, 1889), 106.

The Mahdiyya's supporters called themselves anșā $r$ in reference to the Prophet Muhammad's first disciples in Medina. For a Mahdist proclamation on the adoption of this name, see Francis R. Wingate, Mahdiism and the Egyptian Sudan: Being an Account of the Rise and Progress of Mahdiism, and of Subsequent Events in the Sudan to the Present Time, 2nd ed. (London: F. Cass, 1968), 48.

${ }^{2}$ See George N. Sanderson, "Conflict and Co-operation between Ethiopia and the Mahdist State, 1884 1898," Sudan Notes and Records 50 (1969): 15-40; Richard A. Caulk, "Yohannes IV, the Mahdists, and the Partition of North-East Africa," Transafrican Journal of History 1 (1971): 23-42; Muhammad Sa id alQaddal, The Mahdiyya and Ethiopia, Study in Domestic and Foreign Policies of the Mahdist State, 1881-1898 (in Arabic) (Beirut: Dar al-Jil, 1992).

${ }^{3}$ Paul Ricoeur has elaborated three meanings of the concept: representation as a mnemonic process (the presence to the mind of an absent thing that has been but is not anymore), as a tool of history writing (the historian produces a written discourse claiming to represent the past truthfully), and as an object of historical studies. See Paul Ricoeur, Memory, History, Forgetting (Chicago: University of Chicago Press, 2004), part II, chap. 2-3.

${ }^{4}$ It was not the only important theater of Sudanese-Ethiopian confrontation. For instance, Mahdist forces under amir 'Uthman Abu Bakr Diqna were crushed by Ethiopian troops at the battle of Kufit (23 September 
1885), in present-day Eritrea. See Haggai Erlich, Ras Alula and the Scramble for Africa: A Political Biography: Ethiopia and Eritrea, 1875-1897 (Lawrenceville, N.J.: Red Sea Press, 1996), 68ff.

${ }^{5}$ Such as Rudolf Carl von Slatin (known as Slatin Pasha), Joseph Ohrwalder, Charles Neufeld, and Giuseppe Cuzzi for Sudan and Gerald H. Portal and Sadiq Basha al-Mu'ayyad al- 'Azm for Ethiopia. We mention their respective writings further on.

${ }^{6}$ Muhammad Ibrahim Abu Salim, director of the National Records Office from 1955 till 1995, has published numerous studies on the Mahdist period, as well as critical editions of Mahdist primary sources. See R. S. O'Fahey and Anders Bjørkelo, “The Writings of Muhammad Ibrahim Abu Salim,” Sudanic Africa 1 (1990): 11-18.

${ }^{7}$ Conceptions of the Mahdi vary among Sunnis, but according to Sunni doctrine, the Mahdi should appear before the end of times in order to restore the true religion as well as bring justice to the world. For more details, see Wilferd Madelung, "Al-Mahdi," in Encyclopédie de l'Islam (Leiden: E. J. Brill, 1986), 1221-228; Gabriel R. Warburg, Islam, Sectarianism and Politics in the Sudan since the Mahdiyya (London: C. Hurst and Co., 2002), 22-23.

${ }^{8}$ Robert O. Collins, Egypt and the Sudan (Englewood Cliffs, N.J.: Prentice-Hall, 1967), 72, 77; Peter M. Holt and Martin W. Daly, A History of the Sudan from the Coming of Islam to the Present Day, 5th ed. (London: Longman, 2000), 78; John O. Voll, "The Eastern Sudan, 1822 to the Present," in The History of Islam in Africa, ed. Nehemia Levtzion and Randall L. Pouwels (Athens, Ohio: Ohio University Press, 2000), 154; Warburg, Islam, Sectarianism and Politics, 24.

${ }^{9}$ Aharon Layish, "The Mahdi's Legal Methodology as a Mechanism for Adapting the Sharī $a$ in the Sudan to Political and Social Purposes," Revue des Mondes Musulmans et de la Méditerranée, 91-94 (2000): 223-24; Warburg, Islam, Sectarianism, and Politics, 40-41.

10 "Khalifa" here not merely refers to a caliphal function but is also-and perhaps more importantly—an integral part of the Sudanese leader's name. This historical figure is referred to as Khalifa 'Abdullahi in Sudanese popular and official discourse as well as in most academic writings focusing on Sudan.

${ }^{11}$ Several European prisoners detained in the Mahdist capital (Omdurman) wrote at length about this famine. See Joseph Ohrwalder, Ten Years' Captivity in the Mahdi's Camp, 2nd ed. (London: Sampson Low, Marston \& Co., 1892), 284-91; Rudolf C. Slatin Pacha, Fer et Feu au Soudan, translated from the 8th German edition by G. Bettex (Cairo: F. Diemer, 1898), 591-98; Charles Neufeld, A Prisoner of the Khaleefa: Twelve Years of Captivity at Omdurman, 3rd ed. (London: Chapman and Hall, 1899), 116-18.

${ }^{12}$ Holt and Daly, A History of the Sudan, 90; Warburg, Islam, Sectarianism and Politics, 47.

${ }^{13}$ Negusä nägäst means "king of kings." This title traditionally designated Ethiopian emperors.

${ }^{14}$ Bahru Zewde, A History of Modern Ethiopia, 1855-1974 (London: James Currey, 1991), 44; see also Haggai Erlich, Ethiopia and the Middle East (Boulder, Colo.: Lynne Rienner Press, 1994), 57.

${ }^{15}$ Paul B. Henze, Histoire de l'Ethiopie: l'Euvre du Temps (Paris: Moulin du Pont, 2004), 151. The Tewahedo ("being made one" in Geez) doctrine insists on the single unified nature of Christ as opposed to the belief in the dual nature of Christ espoused by Roman Catholic and Eastern Orthodox churches.

${ }^{16}$ Jean-Baptiste Coulbeaux, Histoire Politique et Religieuse de l'Abyssinie: Depuis les Temps les Plus Reculés Jusqu'à l'Avènement de Ménélick II, 2 vols. (Paris: P. Geuthner, 1929), 2:469.

${ }^{17}$ Hussein Ahmed, Islam in Nineteenth-Century Wallo, Ethiopia (Leiden: E. J. Brill, 2001), 174.

${ }^{18}$ Richard A. Caulk, "Religion and State in Nineteenth-Century Ethiopia," Journal of Ethiopian Studies 10 (1972): 28. The cultivation and use of tobacco were prohibited by the emperor, who associated the substance with Satan and impiety. See Gerald H. Portal, My Mission to Abyssinia (London: E. Arnold, 1892), 14950 .

${ }^{19}$ J. Spencer Trimingham, Islam in Ethiopia (Oxford: Geoffrey Cumberlege for the University Press, 1952), 123. In a letter to Queen Victoria dated 20 November 1879, Yohannes IV presents these conversions as wholly voluntary. See Sven Rubenson, ed., Internal Rivalries and Foreign Threats, 1869-1879 (Addis Ababa, Ethiopia: Addis Ababa University Press, 2000), 333.

${ }^{20}$ Some Ethiopian Muslims fled to Sudan and joined the Mahdiyya. See Sadiq Basha al-Mu'ayyad al'Azm, Rihlat al-Habasha: Min al-Asitana ila Adis Abada, 1896 (Travel to Abyssinia: From Asitana [Istanbul] to Addis Ababa, 1896), 2nd ed. (Abu Dhabi, UAE: Dar al-Suwaydi, 2001), 170.

${ }^{21}$ For instance, Sheikh Talha bin Ja ${ }^{\text {far }}$ declared a jihad in 1884, protesting against the ban on Islamic worship and preaching. It then merged with a wider uprising directed against the taxation policy and execution of a local governor by Ar'aya Sellase (Yohannes IV's son). Ahmed, Islam in Nineteenth-Century Wallo, 178. 


\section{Iris Seri-Hersch}

${ }^{22}$ Caulk, "Yohannes IV, the Mahdists," 25; Berhanou Abebbe, Histoire de l'Ethiopie, d'Axoum à la Révolution (Addis Ababa, Ethiopia: Maisonneuve et Larose, 1998), 107; Henze, Histoire de l'Ethiopie, $148-49$.

${ }^{23}$ Zewde, A History of Modern Ethiopia, 54; Harold G. Marcus, The Life and Times of Menelik II: Ethiopia 1844-1913 (Oxford: Clarendon Press, 1975), 79, 82.

${ }^{24}$ Zewde, A History of Modern Ethiopia, 56.

${ }^{25}$ Sir E. Hertslet, The Map of Africa by Treaty, 3 vols. (London: F. Cass, 1967), 2:422-23 quoted by Marcus, The Life and Times, 81; Abebbe, Histoire de l'Ethiopie, 114-15. For the treaty's background, see the detailed analysis of Zewde Gabre-Sellassie, Yohannes IV of Ethiopia: A Political Biography (Oxford: Clarendon Press, 1975), 122-51.

${ }^{26}$ Francis R. Wingate, Mahdiism and the Egyptian Sudan: Being an Account of the Rise and Progress of Mahdiism, and of Subsequent Events in the Sudan to the Present Time, 2nd ed. (London: F. Cass, 1968), 465.

${ }^{27}$ Al-Qallabat appears as Matamma in Figure 1. Although both names are sometimes used interchangeably to designate the border town, al-Qaddal points out that they were two distinct but adjacent towns. See al-Qaddal, Al-Mahdiyya wa-l-Habasha, 14. Al-Qadarif was also known as Suq Abu Sin.

${ }^{28}$ See n. 1.

${ }^{29}$ A man called Adam Muhammad claimed to be the prophet Jesus and managed to gather many disciples among resentful Mahdist soldiers posted at al-Qallabat. Abu 'Anja reported the event to the khalifa, who had the conspirators executed (December 1887). Al-Dikaym's position remains unclear, but he certainly did not succeed in quelling the revolt. See Wingate, Mahdiism, 334-35; Na 'um Shuqayr, Ta'rikh al-Sudan al-Qadim wa-l-Hadith wa-Jughrafiyatuhu (The History of Ancient and Modern Sudan and Its Geography), 3 vols. (Cairo: n.p., 1903), Muhammad Ibrahim Abu Salim, ed., Ta'rikh al-Sudan (The History of Sudan) (Beirut: Dar al-Jil, 1981), 733-35; Peter M. Holt, The Mahdist State in the Sudan 1881-1898: A Study of its Origins Development and Overthrow (Oxford: Clarendon Press, 1958), 152-53.

${ }^{30}$ Takla-Haymanot is the new name that $\mathrm{ras}$ 'Adal received when he was accorded the title of negus and given control of Gojjam and Kaffa in 1881 .

${ }^{31} \mathrm{Abu}$ Salim and al-Qaddal, Al-Harb al-Habashiyya, 15-16; al-Qaddal, Al-Mahdiyya wa-l-Habasha, $109-10$

${ }^{32}$ Holt, The Mahdist State, 155; Sanderson, "Conflict and Co-operation," 25.

${ }^{33}$ See National Records Office (NRO), MAHDIA 1/34/10B, Balanbras Bozna Venis Balezla Governor of Jelga to En Nur Salaa, early Jumada al-Ula 1312/November 1894; idem, Betwadded Mangasha to the Khalifa of the Mahdi, 6 Safar 1314/17 July 1896; NRO, MAHDIA 1/34/16, Statement of Mohammed Osman El Haj Khaled, n.d.; Sanderson, "Conflict and Co-operation," 26, 28-37.

${ }^{34}$ Caulk, "Yohannes IV, the Mahdists," 26; Erlich, Ethiopia, 71.

${ }^{35}$ Erlich, Ethiopia, 71; Caulk, "Yohannes IV, the Mahdists," 27; Haim Shaked, The Life of the Sudanese Mahdi: A Historical Study of Kitab Sa'adat al-Mustahdi bi-Sirat al-Imam al-Mahdi, the Book of the Bliss of Him Who Seeks Guidance by the Life of the Imam the Mahdi (New Brunswick, N.J.: Transaction Books, 1978), 8; David Robinson, "The Sudan: The Mahdi and Khalifa amid Competing Imperialisms," in idem, Muslim Societies in African History (Cambridge: Cambridge University Press, 2004), 177; Abu Salim and al-Qaddal, Al-Harb al-Habashiyya, 17. The Italians later defeated the Mahdists at Agordat (1893) and occupied Kassala (July 1894).

${ }^{36}$ The book was completed on 6 November 1888. For a critical edition in Arabic, see Muhammad Ibrahim Abu Salim, ed., Sa'adat al-Mustahdi bi-Sirat al-Imam al-Mahdi (Khartoum, Sudan: al-Dar al-Sudaniyya li-1-Kutub; Beirut: Dar al-Fikr, 1972). For an English summary and annotated translation, see Shaked, The Life.

${ }^{37}$ The chronicle was finished on 6 June 1889 according to Abu Salim and al-Qaddal, Al-Harb alHabashiyya, 22. See also Sanderson, "Conflict and Co-operation," 39, n. 4.

${ }^{38} \mathrm{He}$ may have been influenced by Mahdist partisans living in El Obeid but also may have joined the Mahdi out of sincere faith in his mission. Abu Salim nevertheless argues that he acted on pragmatic rather than religious or ideological motives. See Sacadat al-Mustahdi, 17-18; Abu Salim and al-Qaddal, Al-Harb al-Habashiyya, 20.

${ }^{39}$ Historians suggest various explanations for 'Abd al-Qadir's banishment. Jealous of his sociopolitical elevation, the qadi al-Islam Ahmad 'Ali had him slandered in front of the khalifa: Husayn Sayyid Ahmad al-Mufti, Tatawwur Nizam al-Qada' fi al-Sudan (The Development of the Judicial System in the Sudan) (Khartoum, Sudan: n.p., 1959), 140-41. One of 'Abd al-Qadir's descendants claims that the khalifa removed 
the chronicler from the center of the Mahdist state out of fear from a potential alliance with the ashrāf: Abu Salim, Sa' adat al-Mustahdi, 24. In a more global perspective, 'Abd al-Qadir could have counted among the victims of "the great purge which accompanied the transformation of the Mahdist theocracy into an autocracy" between 1892 and 1896: Shaked, The Life, 30.

${ }^{40}$ Sanderson, "Conflict and Co-operation," 28, 38-39; Shaked, The Life, 30.

${ }^{41} \mathrm{Na}$ 'um Shuqayr, who worked in the Egyptian Military Intelligence, obtained this single copy in April 1895 and gave it to his director, Francis W. Wingate. In 1958, the Tiraz was donated to the Sudan Archive of Durham University, where it was rediscovered a decade later. See Shaked, The Life, 35.

${ }^{42}$ Abu Salim and al-Qaddal, Al-Harb al-Habashiyya, 35. Abu Salim argues that the conception of history that prevailed in late 19th-century Sudan implied the extensive use of oral accounts at the expense of written documents: Abu Salim, Al-Haraka al-Fikriyya fi al-Mahdiyya (The Intellectual Movement in the Mahdiyya), 3rd ed. (Khartoum, Sudan: Dar Jami 'at al-Khartum li-1-Nashr, 1989), 214.

${ }^{43}$ Abu Jummayza initiated a massive opposition movement to the Mahdist regime in western Darfur (188889). Thought to possess magical powers, he claimed the vacant position of Khalifa 'Uthman, which the Mahdi had previously offered to Muhammad al-Mahdi bin al-Sanusi. He died a few months after his manifestation and was succeeded by his brother Sagha, who was killed by a victorious Mahdist army (February 1889). See Holt, The Mahdist State, 136-40; Lidwien Kapteijns, Mahdist Faith and Sudanic Tradition: The History of the Masalit Sultanate 1870-1930 (London: Routledge \& Kegan Paul, 1985), 83-94.

${ }^{44}$ Abu Salim and al-Qaddal, Al-Harb al-Habashiyya, 25-26.

${ }^{45}$ See n. 29.

${ }^{46}$ Such as the correspondence between amir Abu 'Anja and negus Takla-Haymanot during the first half of 1888. See, for instance, NRO, MAHDIA 1/34/16A/38, Hamdan Abu 'Anja to negus Takla-Haymanot, 15 Jumada al-Akhira 1305/27 February 1888; NRO, MAHDIA 1/34/10B/163 negus Takla-Haymanot to Hamdan Abu 'Anja, 30 Sha'ban 1305/12 May 1888.

${ }^{47} \mathrm{Such}$ as the episode of al-Nabi 'Isa and the ashräf opposition. Their mention could indeed call into question the validity of the khalifa's position. The khalifa's authority is reinforced by the fact that in the Tiraz he is the only protagonist who corresponds with the Ethiopian enemy. Letters sent by other Mahdist leaders are totally excluded.

${ }^{48}$ In the Tiraz, Yohannes IV embodies the leader of the Ethiopian unbelievers and is accused of having attacked dār al-Isläm. 'Abd al-Qadir does not mention his peace proposal to the khalifa (25 December 1888) in order not to erode the emperor's image as an aggressor.

${ }^{49}$ Abu Salim, Al-Haraka al-Fikriyya, 209.

${ }^{50}$ This Mahdist division of the world replaced the classical Islamic distinction between dār al-Islām and dār al-harb.

${ }^{51}$ Al-Qaddal quoted by Warburg, Islam, Sectarianism, and Politics, 32. Although the term Turk was initially used by 19th-century Sudanese to refer to their Turco-Egyptian rulers, it came to encompass all non-Sudanese political and military elites in Sudan. The Anglo-Egyptian administration established in 1899 was thus called the "second Turkiyya" in opposition to the "first Turkiyya" dating from the 1820-85 period.

${ }^{52}$ Habasha historically refers to the country's inhabitants rather than to a territory. Derived from this Arabic root, the term Abyssinia was attributed a territorial meaning in its European uses.

${ }^{53}$ Abu Salim and al-Qaddal, Al-Harb al-Habashiyya, 56. 'Abd al-Qadir probably evokes the beginning of Turco-Egyptian rule in the Sudan, during which the town of al-Qallabat was subordinated to Ethiopia (until 1838). See al-Qaddal, Al-Mahdiyya wa-l-Habasha, 15.

${ }^{54} \mathrm{Abu}$ Salim and al-Qaddal, Al-Harb al-Habashiyya, 58-59. It is here referring to the battle in which Arbab was killed by the Ethiopians (al-Qallabat, January 1887). The exaggerated number of 20,000 Mahdist victims, which is mentioned in an Egyptian Military Intelligence report, should undoubtedly be reduced to a few thousand. See NRO, CAIRINT 1/29/148, "War between Derviches and Abyssinians," and al-Qaddal, Al-Mahdiyya wa-l-Habasha, 55.

55 'Abd al-Qadir quotes a Qur'anic verse to strengthen the link between Mahdist military strategy and divine will: "God surely likes those who fight for his cause in ranks, as if they were a solid construction" (61:4). See Abu Salim and al-Qaddal, Al-Harb al-Habashiyya, 82.

${ }^{56}$ Ibid., 98-99.

${ }^{57}$ Ibid.

${ }^{58}$ For instance, Mahdist fighters are reported to have seen the khalifa leading their army to battle, although he was actually in Omdurman at the time. Some of them witnessed men with white flags coming down from 
the sky to help them fight the infidels. Ten months before the battle, the khalifa had a prophetic vision in which the Prophet informed him of a coming Mahdist victory against the Ethiopians. On the battlefield, fire burns miraculously "devoured the body of killed enemies." Ibid., 109, 110, 111, n. 1.

${ }^{59}$ Ibid., 103.

${ }^{60}$ The matab is a cordon that Christian Ethiopians wore around their necks to mark their religious affiliation. See Viviane A. Yagi, Le Tiraz: Chronique sur la Guerre Soudano-Abyssine de 1885-1889 (Omdurman, Sudan: n.p., 1984); unpublished French translation of Isma 'il 'Abd al-Qadir al-Kurdufani, Al-Tiraz al-Manqush biBushra Qatl Yuhanna Malik al-Hubush (Omdurman, Sudan: handwritten manuscript by the kātib Muhammad Ahmad Hashim 1889), 198, n. 96.

${ }^{61}$ The title of 'Abd al-Qadir's book is in this regard very evocative. Using the term tiraz refers to a caliphal prerogative because the embroideries and robes called by this name from the Umayyad until the Fatimid period symbolized the khalifa's power. See Yedida K. Stillman and Paula Sanders, "Tiraz," in Encyclopédie de l'Islam (Leiden: E. J. Brill, 2002), 573-78. Rather than being inscribed with Khalifa 'Abdullahi's name-traditional tiraz bore the khalifa's name-'Abd al-Qadir's Tiraz is decorated with the name of the vanquished enemy. Yohannes IV's defeat is thus transformed into an attribute of the khalifa.

${ }^{62}$ The expression "Mahdist attitudes" here refers to the stance of Mahdist political and military elites rather than to the attitudes of Sudanese society as a whole.

${ }^{63}$ For the former, see Ahmad Ibrahim Abu Shouk, "Ideology versus Pragmatism-The Case of the Mahdist Public Treasury in the Sudan (1881-1898)," Die Welt des Islams 46 (2006): 152; Ahmed Uthman Ibrahim, "Some Aspects of the Ideology of the Mahdiya," Sudan Notes and Records 60 (1979): 32. For the latter, an Italian prisoner of the Mahdists wrote that in 1884, the Mahdi claimed he would take Khartoum, conquer Egypt, overthrow the Ottoman sultan, and then defeat Europe: Giuseppe Cuzzi, Fifteen Years Prisoner of the False Prophet (Khartoum, Sudan: Sudanese Heritage Series no. 3, Sudan Research Unit, 1968), 103. Sanderson emphasizes that the Mahdi's divine mission aimed at converting the whole world: "Conflict and Co-operation," 15.

${ }^{64}$ These places appear in a proclamation decreed by the Mahdi after the fall of El Obeid (January 1883):

The Apostle of God . . . said to me, "As thou didst pray in El Obeid, thou shalt pray in Khartoum, then ... in the mosque of Berber, then . . . in the Holy House of God, then . . . in the mosque of Yathrib, then . . . in the mosque of Cairo, then ... in the mosque of Jerusalem, then . . in the mosque of al- 'Iraq, then you shalt pray in the mosque of al-Kufa."

Letter-Book of al-Nujumi, 1st unnumbered folio, quoted by Peter M. Holt, "The Sudanese Mahdia and the Outside World," Bulletin of the School of Oriental and African Studies 21 (1958): 278. This observation contradicts Cuzzi's account, the reliability of which can be legitimately called into question, because it was published in a context of harshly anti-Mahdist British propaganda.

${ }^{65}$ Muslim territories comprised West and North Africa, Egypt, the Ottoman Empire, and the Arabian peninsula. Most of the letters sent to leaders of these areas produced no results, although Mahdist beliefs were popular in the territories of the Sokoto Caliphate (1804-1903) and the ancient empire of Bornu (1396-1893). See Warburg, Islam, Sectarianism and Politics, 46; Holt, "The Sudanese Mahdia," 283-88.

${ }^{66}$ For the former, see Sanderson, "Conflict and Co-operation," 15; Viviane A. Yagi, Khalifa Abdullahi: Sa Vie et Sa Politique (PhD diss., Montpellier III, University of Lille, France, 1990), 505; Abu Salim and al-Qaddal, Al-Harb al-Habashiyya, 9. For the latter, see Cuzzi, Fifteen Years, 104, and Holt, "The Sudanese Mahdia," 289.

${ }^{67}$ Yagi applies this last conception to Sudanese-Ethiopian and Sudanese-British hostilities: Yagi, Khalifa Abdullahi, 507. Jihad's defensive function is related to ribāt, which implies the defense of dār al-Islām by forces located in ports and border towns (thughūr). See Majid Khadduri, War and Peace in the Law of Islam (Baltimore, Md.: Johns Hopkins Press, 1955), 81.

${ }^{68}$ Abu Shouk, "Ideology versus Pragmatism," 158-59.

${ }^{69}$ Al-Qaddal, Al-Mahdiyya wa-l-Habasha, 40; Warburg, Islam, Sectarianism and Politics, 32-33.

${ }^{70}$ Holt and Daly, A History of the Sudan, 89; Caulk, "Yohannes IV, the Mahdists," 28; Warburg, Islam, Sectarianism and Politics, 47.

${ }^{71}$ Merid Wolde Aregay and Sergew Hable Selassie, "Sudanese-Ethiopian Relations before the Nineteenth Century," in Sudan in Africa, ed. Yusuf Fadl Hasan, 2nd ed. (Khartoum, Sudan: Khartoum University Press, 2006), 64-65; Mordechai Abir, "The Origins of the Ethiopian-Egyptian Border Problem in the Nineteenth Century," Journal of African History 8 (1967): 443, 448, 450, 459. 
${ }^{72}$ Holt, "The Sudanese Mahdia," 287; Erlich, Ethiopia, 63, 66; Abu Salim and al-Qaddal, Al-Harb alHabashiyya, 10, 12; Sanderson, "Conflict and Co-operation," 17.

${ }^{73}$ Holt and Daly, A History of the Sudan, 89; Abu Salim and al-Qaddal, Al-Harb al-Habashiyya, 12-13.

${ }^{74}$ Although the Aksumite ruler's name is Adriaz in Ethiopian and European writings, it varies in Islamic sources: Ashama, Askhama, Mashama, Sahma, Ashaba. He was usually known as al-najāshī, a term borrowed from the Geez nägâsî that designates the ruler. European languages transformed it into negus. See 'Abdallah El Tayeb, "On the Abyssinian Hijrah," Sudan Notes and Records, no. 2 (1998): 160; Emeri Van Donzel, "Al-Nadjashi," in Encyclopédie de l'Islam (Leiden: E. J. Brill, 1993), 863.

${ }^{75}$ Historians diverge on the exact Qur'anic verses that he quoted in front of Adriaz, but sura 19 (Maryam) seems to have been recalled. See Van Donzel, "Al-Nadjashi," 864; Erlich, Ethiopia, 7-8; El Tayeb, "On the Abyssinian Hijrah," 161.

${ }^{76}$ Erlich, Ethiopia, 9.

${ }^{77}$ Ibid., 15.

${ }^{78}$ For more details, see Khadduri, War and Peace, 252-67.

${ }^{79}$ Ibid., 252.

${ }^{80}$ Ibid., 256; Van Donzel, “Al-Nadjashi,” 865.

${ }^{81}$ Khadduri, War and Peace, 255-56; Erlich, Ethiopia, 9.

${ }^{82}$ Ibn Ishaq quoted by Van Donzel, "Al-Nadjashi," 864.

${ }^{83}$ The Solomonic dynasty was established in 1270 on the Ethiopian highlands (Shoa) and claimed direct lineage from the Aksumite kings, who themselves claimed direct descent from King Solomon and the Queen of Sheba.

${ }^{84}$ Trimingham, Islam in Ethiopia, 85.

${ }^{85}$ See Trimingham, Islam in Ethiopia, 86, n. 2.

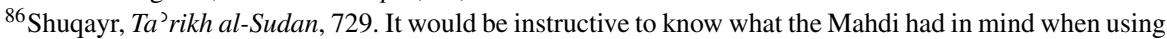
the expression jamī`al-'ard ("the whole earth").

${ }^{87}$ Erlich, Ethiopia, 67.

${ }^{88}$ MAHDIA Y80, 1. MSS Letter-Book of Uthman Diqna, SOAS 101491 khalifa to 'Uthman Diqna, Muharram 1303/October 1885, and khalifa to 'Uthman Diqna, 21 Muharram 1303/31 October 1885 quoted by Erlich, Ras Alula, 65 .

${ }^{89}$ Abu Salim and al-Qaddal, Al-Harb al-Habashiyya, 71.

${ }^{90}$ Ibid., 70; Shuqayr, Ta'rikh al-Sudan, 730.

${ }^{91}$ Although the Mahdist armies did not launch any major attack against Ethiopia until January 1888, frequent bidirectional raids had taken place in the border zone since the end of 1885. See al-Qaddal, $A l$ Mahdiyya wa-l-Habasha, 55-59.

${ }^{92}$ Shuqayr, Ta ${ }^{3}$ rikh al-Sudan, 736.

${ }^{93}$ Wingate, Mahdiism, 370; Muhammad Sa Cid al-Qaddal, Ta 'rikh al-Sudan al-Hadith: 1820-1955 (History of the Modern Sudan: 1820-1955) (Khartoum, Sudan: Sharikat al- 'Amal li-1-Tiba 'a wa-1-Nashr, 1993), 198.

${ }^{94}$ NRO, MAHDIA 1/34/1/64, Hamdan Abu 'Anja to Yohannes of Ethiopia, Jumada al-Ula 1306/January 1889.

${ }^{95}$ Ibid.

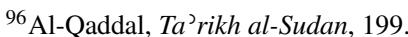

${ }^{97}$ Al-Qaddal, Al-Mahdiyya wa-l-Habasha, 123. Ethiopia was indeed threatened by Italian advances from the coastal town of Massawa and suffered from many internal power struggles.

${ }^{98}$ The Mahdi had often used prophetic visions in order to proclaim the new laws of the Mahdist state. As the Prophet's heir (wārith) and successor (khalīfat rasül Allah), he claimed the ability to communicate directly with the Prophet. See Layish, "The Mahdi’s Legal Methodology," 223.

${ }^{99}$ NRO, MAHDIA 3/12 (Daftar al-Sadir), 9.

${ }^{100}$ According to Ethiopian traditions, forty-four churches were devastated. The sight of Gondar in flames brought back the specter of Ahmad Grañ to Ethiopian minds. See Erlich, Ethiopia, 70.

${ }^{101}$ Abu Salim and al-Qaddal, Al-Harb al-Habashiyya, 127. 